\title{
First records of gall-inducing aphid Pemphigus populi (Hemiptera: Aphidoidea, Eriosomatidae) in Poland with gall-based key to Central and North European species of the genus
}

\author{
Barbara Osiadacz \& Roman Halaj
}

Osiadacz, B. \& Hałaj, R. 2014: First records of gall-inducing aphid Pemphigus populi (Hemiptera: Aphidoidea, Eriosomatidae) in Poland with gall-based key to Central and North European species of the genus. - Entomol. Fennica 25: 1626.

The paper presents first records of Pemphigus populi Courchet, 1879 (Hemiptera, Aphidoidea, Eriosomatidae) from Poland with a short description of the morphological characteristics of its fundatrix and fundatrigenia. Special attention is paid to the characteristics which distinguish this species from other Polish as well as the Central and North European representatives of this genus on poplars (Populus spp.). Information on the biology and distribution of $P$. populi in the world are given. A key to Central and North European species of Pemphigus, based on their galls formed on the primary host plants is also provided.

B. Osiadacz, Poznań University of Life Sciences, Department of Entomology and Environmental Protection, Dąbrowskiego 159, 60-594 Poznań, Poland; E-mail: osiadacz@up.poznan.pl

R. Hałaj, The Upper Silesian Nature Society, Huberta 35, 40-543, Katowice, Poland;E-mail:roman-halaj@hotmail.com

Received 25 April 2013, accepted 18 October 2013

\section{Introduction}

The world's aphid fauna of Pemphigus Hartig, 1839 includes over 70 species (Remaudière \& Remaudière 1997, Blackman \& Eastop 2006, Holman 2009), out of which 20 have been recorded in Europe (Nieto Nafría et al. 2012). So far 9 species have been reported from Poland (Barczak 1987, Osiadacz \& Hałaj 2009, 2010). Here we present the first records of Pemphigus populi Courchet, 1879 from Poland, thus introducing the 10th species of this aphid genus in the country, with a short description of morphological characteristics of the fundatrix and fundatrigenia as well as notes on the biology and distribution of the species.
Pemphigus spp. includes both holocyclic (with full developmental cycle) and heteroecious species (which in their seasonal cycle change the host) and anholocyclic (breeding only by parthenogenesis) monoecious ones (Zwölfer 1958, Lampel 1960, Heie 1980, Nieto Nafría et al. 2002, Stroyan 2009) (Fig. 1), an exception being the holocyclic and at the same time monoecious P. spyrothecae Passerini, 1856 (Urban 2002, Osiadacz \& Hałaj 2011). All the holocyclic Pemphigus spp. induce galls on their primary hosts [Populus L. subgenus Eupopulus Dode, especially of the section 'black' Aigeiros Duby (Figaj \& Stecki 1979)] (e.g. Dunn 1960, Shaposhnikov 1964, Whitham 1978, Smith 1985, Wool 2004, Pike et al. 2007). Both the gall shape and location 


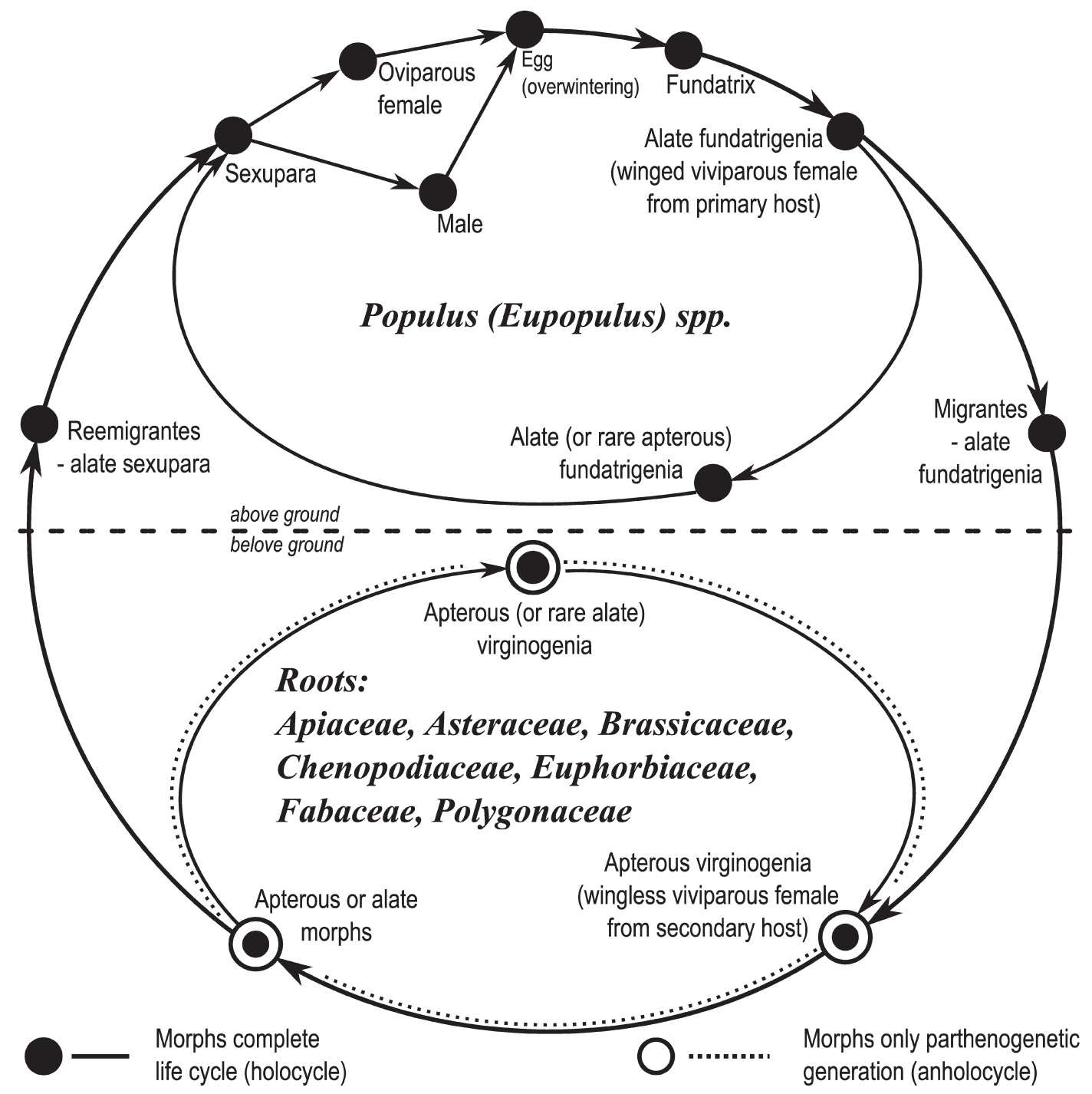

Fig. 1. Life cycles of Central and North European Pemphigus spp.

on the plant (Fig. 2) are characteristic enough to enable to differentiate particular species of Pemphigus spp. Accordingly, an original identification key of North and Central European Pemphigus species is presented on this basis.

\section{Material examined}

The material consists of numerous fundatrices as well as numerous alate fundatrigeniae and nymphs which are all greyish green and highly wax powdered in galls on leaves of black poplar
Populus nigra L. (Fig. 3). They were recorded at four localities (Fig. 4) as follows: 15.V. (fundatrices and nymphs) and 8.VI.1996 (alatae fundatrigeniae and nymphs), and 14.V.2011 (fundatrices and nymphs), Ruda Śląska-Bykowina (Silesian Upland) UTM: CA47; 08.VI.2012 (alatae fundatrigeniae and nymphs), Górki near Wiślica (Nida Basin), UTM: DA87; 24.VI.2012 (alatae fundatrigeniae and nymphs), Gruczno (Lower Vistula Valley), UTM: CE21; 17.VI. 2012 (alatae fundatrigeniae and nymphs), Ligota Dolna-Kamieniołom (Silesian Upland) UTM: BA99. 


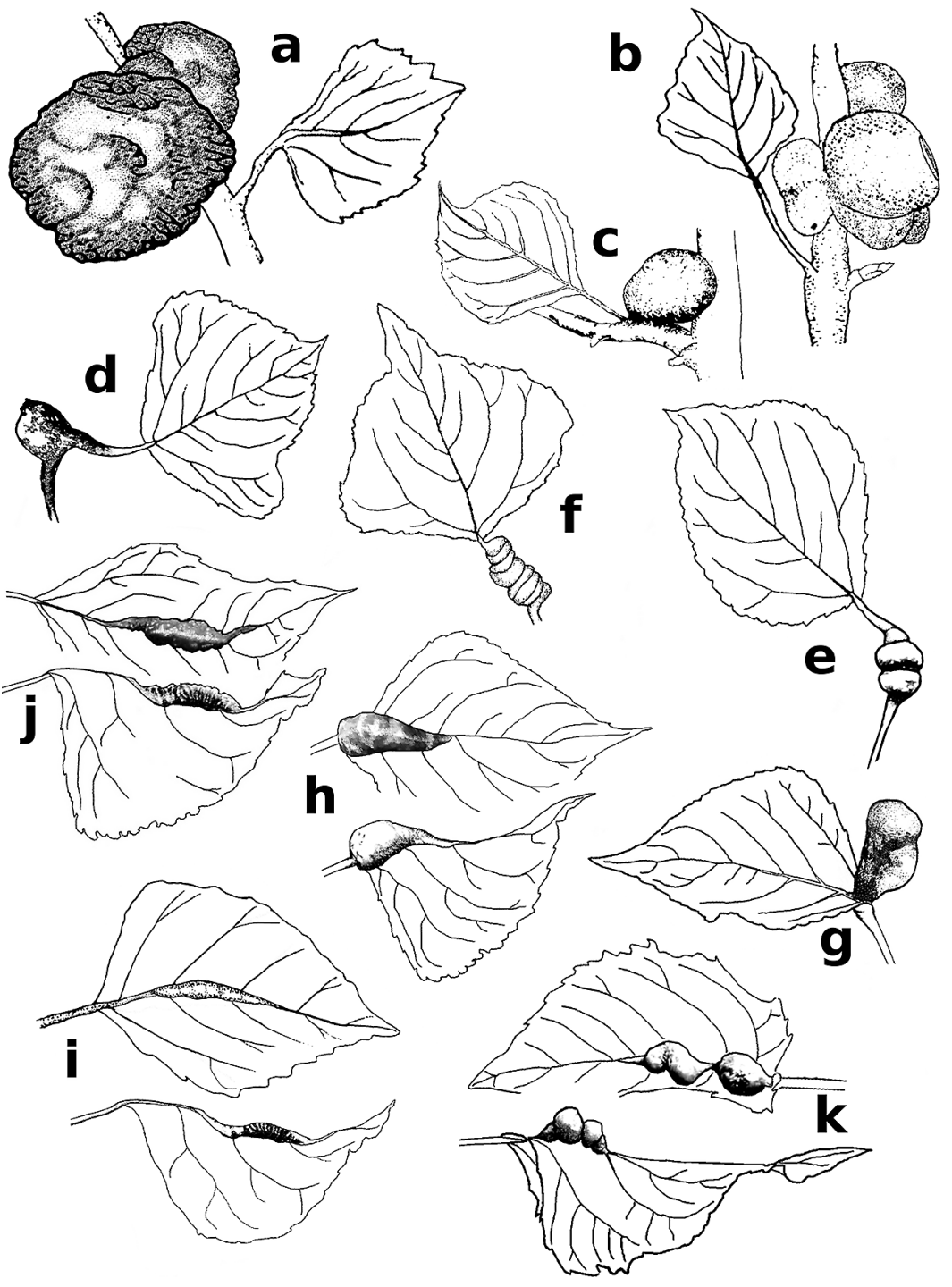

Fig. 2. Gall-inducing Pemphigus spp. - a. P. immunis. - b. P. borealis. - c. P. trehernei (modified draft based on Heie (1980)). $-d$. $P$. bursarius. - e. $P$. spyrothecae. - f. $P$. protospirae. - g. P. populi. - h. P. passeki (modified draft based on Prinsen (1990)). $-\mathrm{i}$. $P$. gairi. $-\mathrm{j}$. $P$. phenax. $-\mathrm{k} . P$. populinigrae.

\section{Main morphological characters}

Fundatrix. Body 2.4-2.7 mm, abdominal wax gland plates (secrete wax substances) consisting of a few and rather large facets; anntenae 4-segmented, about 0.17 times body length; antenna segment III 0.7-0.95 times the length of segment IV.

Fundatrigenia (Fig. 5). Body 1.5-2.4 mm, abdomen with small but distinct marginal wax gland plates; apical segmet of rostrum pointed (Fig. 5b), about $0.1-0.12 \mathrm{~mm}$ and $0.5-0.7$ times as long as the 2 segment of the hind tarsus; antenna segment III 0.9-2.4 times the length of segment IV; antenna segment V nearly the same length as IV; processus terminalis (VIb) 0.25-0.4 times as long as basal part (VIa) of antenna segmet VI; secondary rhinaria on antenna segments IV and V rather oval and wide - greater than rhinaria on antenna segment III (Fig. 5a); the number of secondary rhinaria on segment $\mathrm{V}$ are 1 or 2; siphunculi pores absent (Fig. 5c).

The latter two traits are basic morphological hints which help quickly differentiate winged viviparous females (fundatrigenia) of this species (subgenus Pemphiginus Börner, 1930 (e.g. Börner 1952, Barbagallo et al. 1995, Nieto Nafría et al. 2002) from other species of Pemphigus infesting poplars, belonging to Pemphigus s. str. 
Fig. 3. Gall-inducing Pemphigus populi.

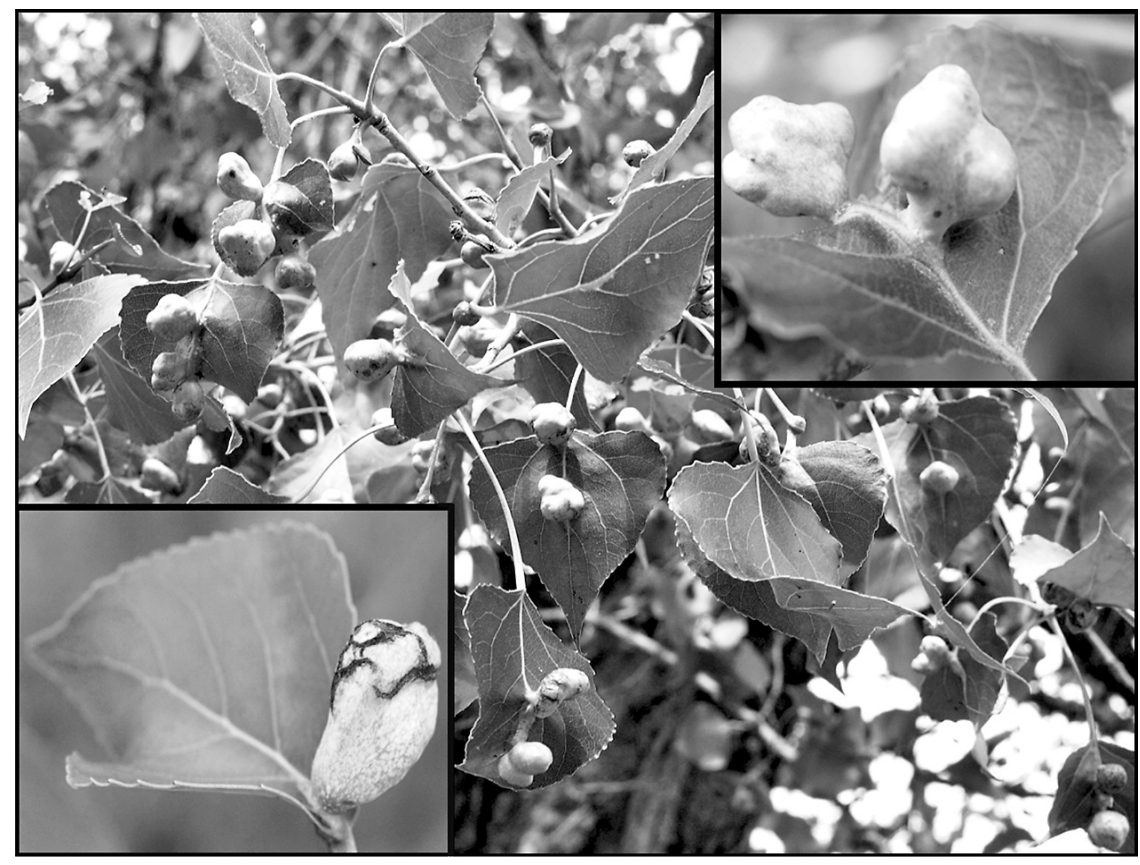

Fig. 4. Distribution of Pemphigus populi in Poland. 1: Gruczno, 2: Ligota Dolna, 3: Ruda Śląska, 4: Górki.

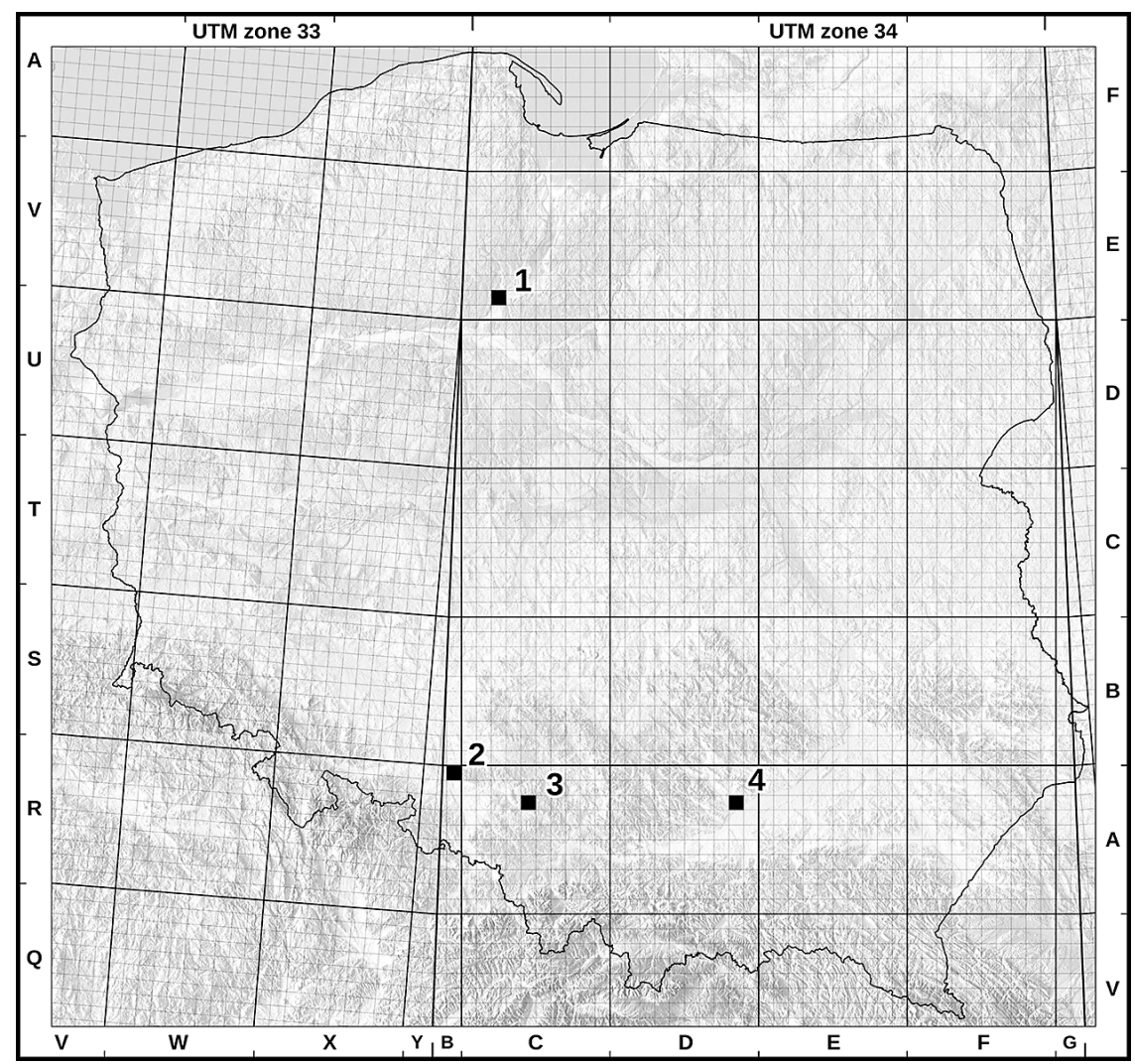




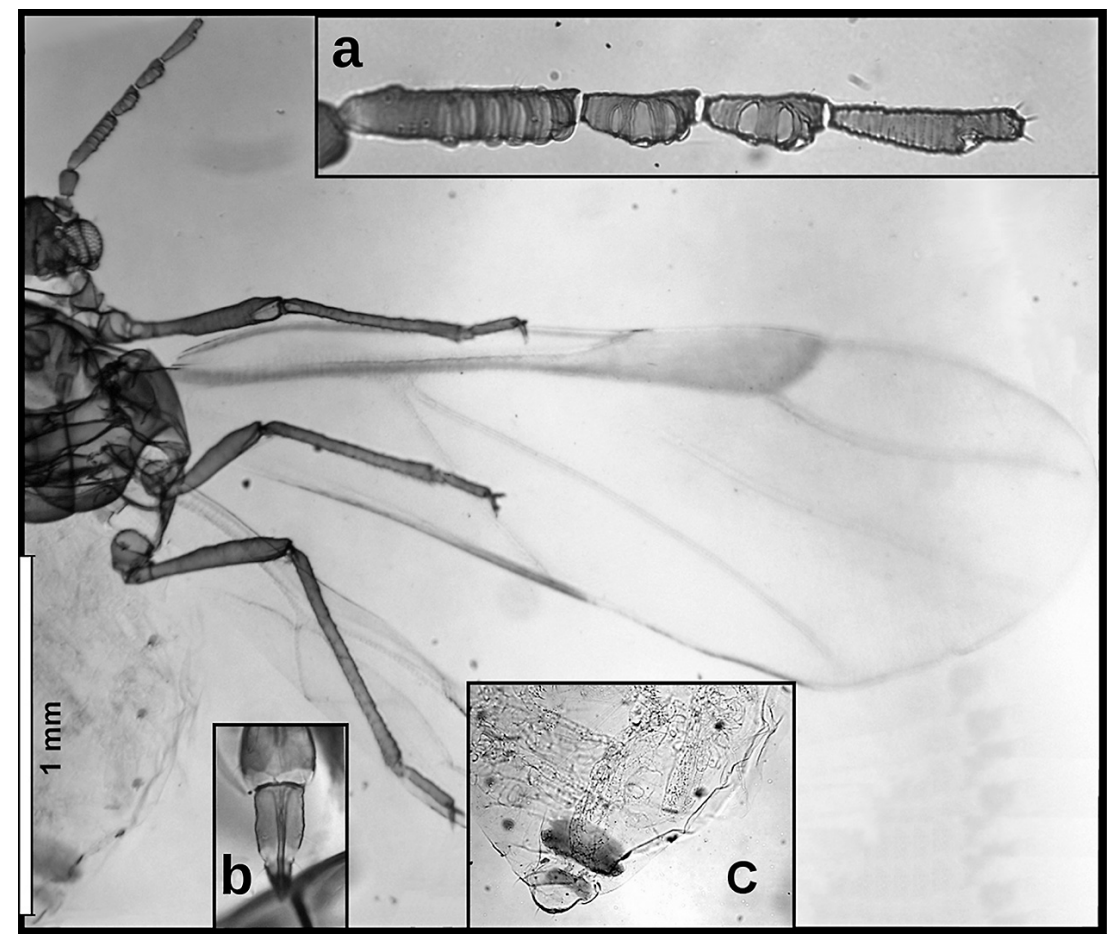

Fig. 5. Alate fundatrigenia of Pemphigus populi. - a. Flagellum. - b. Ultimate rostral segment. - c. Tip of abdomen.

\section{Biology}

Pemphigus populi is a holocyclic and heteroecious species (see Fig. 1). Its primary host plants are various poplar species of Eupopulus subgenus, mainly the black poplar (Populus nigra) and its Italian variety ( $P$. nigra 'Italica'). The infestation causes characteristic galls (Fig. 2g, 3). They are induced by fundatrices, which hatch from fertilised overwintering eggs on the break of April and May. The first young galls in Poland were observed in the first half of May (15.V.1996, 14.V.2011) and mature ones were seen already at the beginning of June (08.VI.2012) with numerous alate fundatrigeniae feeding inside. The opening of the galls and the flowing out of the migrantes were noted in the second half of June (17 and 24.VI.2012).

Secondary host plants for $P$. populi are various species of Fabaceae (e.g. Lathyrus pratensis L., Medicago lupulina L., Melilotus altissimus Thuill.) and the infested place most often include ground and underground plant parts, particularly small roots (Danielsson 1976). Here the large generation of wingless viviparous females (apterous virginogenia) develops and on the break of September and October, reemigrantes (alate sexuparae) come back to the primary host plants (Furk \& Prior 1975) and breed the sexual generation (oviparous females and males). The life cycle ends with laying eggs on poplar twigs (Fig. 1).

\section{Zoogeography}

Pemphigus populi has been reported on vast areas of the Palaearctic from the British Isles (Stroyan 1957) to Western Siberia (Ivanovskaja 1977) (Fig. 6). A more detailed analysis shows that most locations form a belt approximately along the 40th parallel of north latitude from the Iberian Peninsula (e.g. González Funes \& Michelena Saval 1988, Pérez Hidalgo \& Nieto Nafría 2003) and other regions of the northern Mediterranean coast: Croatia, France-Corsica, Slovenia, Turkey, Italy (Courchet 1879, Çanakçioglu 1966, 1972, Janežič, 1978, 1981, 1989, Roberti 1993, Lampel 2001) through the Caucasus (Dzhibladze 1968) to Central Asia (Narzikulov 1953, 1968, Juchnevitch 1968, Bozhko 1976, Mukhamediev 1979, Gabrid 1989). In some regions of the belt, a clear shift of locations towards the $50^{\text {th }}$ parallel is 


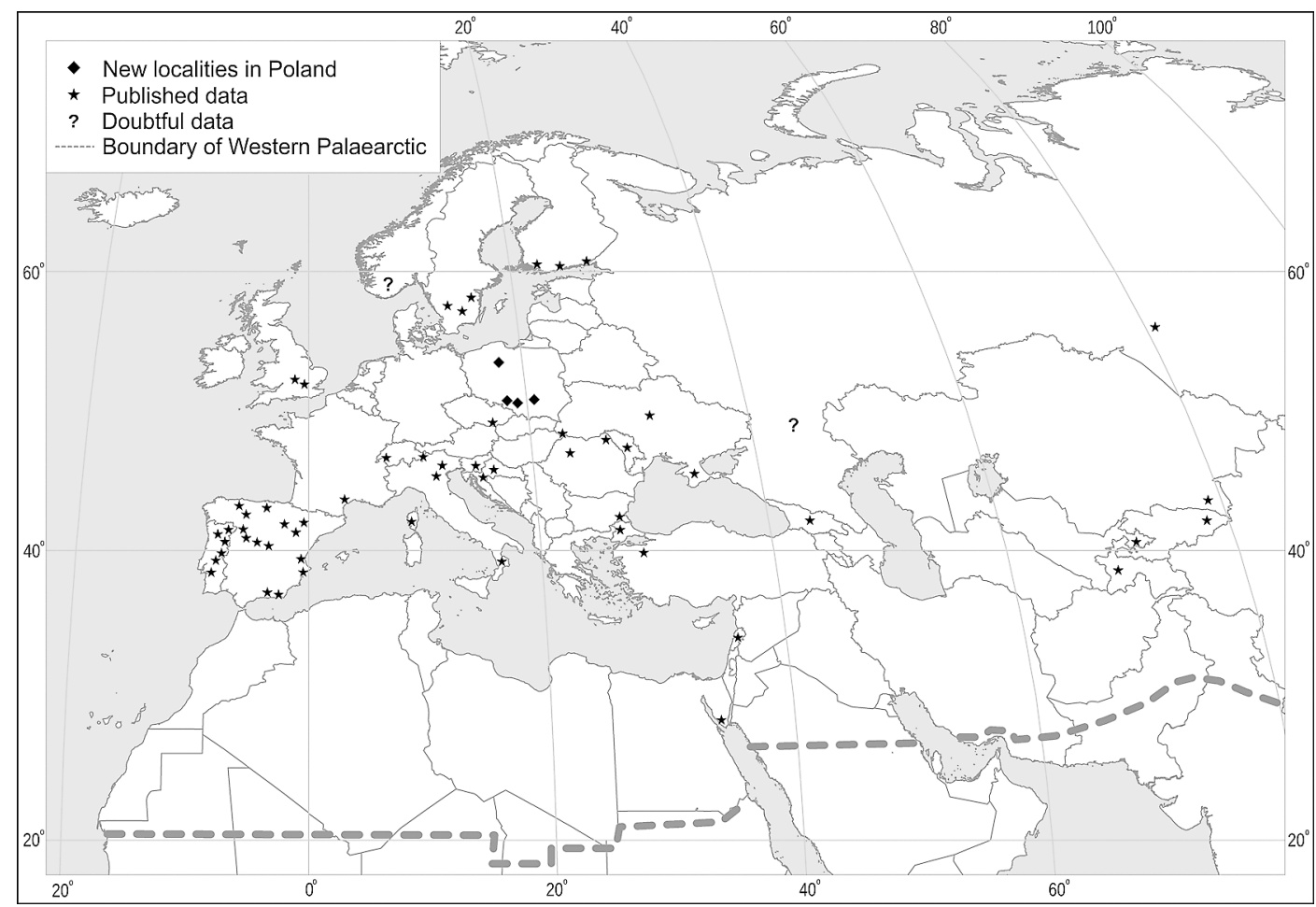

Fig. 6. Occurrence of Pemphigus populi in Western Palaearctic.

obvious, particularly between $25^{\text {th }}$ and $35^{\text {th }}$ meridian of eastern longitude, as the localities from Bulgaria, Romania, Moldova and southern Ukraine (including Crimea) (e.g. Mamontova 1949, 1955, Bozhko 1957, 1971, 1976, Vereshchagin \& Vereshchagina 1962, Holman \& Pintera 1981, Vereshchagin et al. 1985, Tashev 1985, Gabrid 1989, Chumak 2004) are in those areas.

Therefore, $P$. populi is a species of western Palaearctic range and more exactly of a Mediterranean-Pannonian-Pontian-Central Asian element. Some single reports from those centres of occurrence, e.g. Lebanon (Bodenheimer \& Swirski 1957) or the Sinai Peninsula in Egypt (El-Akkad \& Zalat 2004), seem to corroborate the species character (i.e. Mediterranean).

On the other hand, less numerous reports from other areas, e.g. from the Czech Republic (Lampel 1988, Holman 1995, Lampel \& Meier 2003), Switzerland (Lampel, 1988, Lampel \& Meier
2003), Sweden (Danielsson 1976), and Finland (Albrecht 2013), may indicate that it is increasing its range. The thesis seems to be supported by finding its new localities in Poland. In spite of rather detailed aphidological research conducted in the previous century in Silesian Upland, Wielokopolsko-Kujawska Lowland or Nida Basin on Małopolska Upland (Krzywiec 1970, 1982, Olesinski \& Szelegiewicz 1974, Achremowicz 1972, 1975, Klimaszewski et al. 1980, Szelegiewicz 1981, Czylok 1983, Czylok \& Wojciechowski 1987, Czylok et al. 1991, Karwańska 1991, Hałaj 1996, 1998, Hałaj \& Weggierek 1998, Osiadacz \& Wieczorek 2003, Wieczorek \& Osiadacz 2005) and finding many aphid taxa there (Szelegiewicz 1968, Osiadacz \& Hałaj 2009), the species in question was not found then. It seems impossible that $P$. populi, with such characteristic galls, had been overlooked. Therefore, at the moment, the species is quickly (almost invasively) expanding its range. 


\section{Key to central and north European species of Pemphigus, with additional notes on their biology and distribution}

The key is based on the galls formed by the aphids on their primary hosts of Populus L. (subgenus Eupopulus). Below, migrating refers to the host alternation between the primary and secondary host plants of the aphids.

1. Galls on twigs

- Galls on the petiole or lamina

2. Galls small, maximum diameter $2.5 \mathrm{~cm} 3$

- Galls clearly longer, of walnut size (about 4 $\mathrm{cm}$ in diameter), more or less spherical, with thick walls and uneven, wrinkled and often cracked surface, usually occurring individually, less often in small groups $(1-4)$ but always separated from one another (Fig. 2a)

P. immunis Buckton, 1896

(syn.: P. lichtensteini Tullgren, 1909)

The species is holocyclic and heteroecious, migrating to the roots of Euphorbia spp. (especially E. helioscopia L. and E. peplus L.). It is common in the Palaearctic region, occurring also in the Oriental region. However, its occurrence is rarely reported. In Central Europe, it is known from almost all countries, but it has not been listed in Denmark, Norway, Sweden, Finland, Estonia, Latvia and Lithuania.

3. Galls more or less oval in shape and with a rather smooth surface, often merged into groups of 4-6 at the base (even up to 10), but with separate fly-out zones for migrants (Fig. 2b)

P. borealis Tullgren, 1909

The species is holocyclic and heteroecious, migrating between Populus and underground parts of Bidens spp. (B. tripartita L., $B$. cernua L.). It occurs in the Palaearctic region, especially its northern part. It is known in Europe from Sweden and Finland, Estonia, Latvia, and Kaliningrad Region (Russia) and from a few localities in the other parts of the Europe.

- Galls single, rather round and smooth on the surface (Fig. 2c), green with reddish edge around the inlet P. trehernei Foster, 1975

The species is holocyclic and also anholo- cyclic on the secondary hosts (Aster tripolium L., Solidago virgaurea L.). It is known from southern and western Europe (Ireland, France, United Kingdom). So far it has not been found in Central and Northern Europe.

4. Galls on the petiole 5

- Galls on the lamina 7

5. Galls more or less spherical, pear-shaped or pouch-like (Fig. 2d), green, yellow-green, sometimes red-brown in colour

P. bursarius (Linnaeus, 1758)

The species is holocyclic and heteroecious, migrating to the roots of Asteraceae (mainly Crepis spp., Lactuca spp., Lapsana spp., Taraxacum spp., Tussilago spp.). It is cosmopolitic.

- Galls of other shapes, mainly spiral 6

6. Galls in the form of flattened and spirally twisted petiole, with the number of twists not exceeding 5 (usually 3-4) (Fig. 2e). Galls green, yellow-green to red-brown, open at the end of summer and the beginning of autumn, often only in November

P. spyrothecae Passerini, 1856

The species is holocyclic and monoecious, occurring in Europe (recorded in all countries in Central and North Europe), Western Siberia, Northern Africa and the Middle East. It has been introduced to Canada.

- Galls flattened and strongly spirally twisted, the twists are smaller and more numerous (more than 5) than those formed by P. spyrothecae. Galls very often on all the petiole and the base of the lamina (Fig. 2f), shiny, green or green with red spots, opening from the beginning of summer until midsummer

P. protospirae Lichtenstein, 1884, 1885

The species is holocyclic and heteroecious, migrating to the plants of Apiaceae, especially those growing in water (e.g. Apium spp., Berula spp., Sium spp.). It occurs in Europe, Western Siberia and Central Asia. In Central and Northern Europe, it is known from few single localities in several countries (Denmark, Germany, Poland, Sweden, Slovakia, Belarus, Kaliningrad Region-Russia).

7. Galls more or less spherical or oval, more or less irregularly blobbed, almost always narrower at the base than at the top, pear-shaped or even slenderer (baseball bat-shaped), 
placed on the upper side of the lamina on the main nerve usually close to its base (Fig. $2 \mathrm{~g}$, $3)$, size of a hazelnut, most often green in colour P.populi Courchet, 1879

- Galls elongated and running along the main nerve

8. Galls at the base of the lamina, widest at base, then distinctly tapering (Fig. 2h)

P. passeki Börner, 1952

The species is holocyclic and heteroecious, migrating to the basal parts and roots of Carum carvi L. It is so far known from NorthWestern Europe as well as Finland and Ukraine.

- Galls of other shape, but never commencing at base of leaf lamina, never widened at base 9

9. Galls elongated and very narrow, their width at most 3-4 times the width of the main nerve, formed most often in the middle of the lamina (Fig. 2i), rather thin-walled and always slightly shining, green-yellow in colour, rarely slightly reddish P. gairi Stroyan, 1964

The species is holocyclic and heteroecious, migrating to the roots of Aethusa cynapium L. It is known from England, Czech Republic and Ukraine.

- Galls of other shape, but always much wider (minimum of 5 times the width of the main nerve) than in the previous species

10. Galls spindle-like, with slightly wrinkled surface (Fig. 2j), more or less red in colour, often with yellow sides and open all along from the bottom side of the lamina

P. phenax Börner \& Blunck, 1916

The species is holocyclic and heteroecious, migrating to the roots of carrots (Daucus carota L.). It occurs in the Palaearctic region but it is rare or local. In Central and Northern Europe, it is known from most countries except Estonia, Finland, Latvia and Lithuania.

- Galls elongated and running along the main nerve, but much wider than those formed by $P$. phenax, blisterous, hazelnut size (but not larger) (Fig. 2k), rather smooth, in their majority bright reddish (rarely greenish) and rather without yellowish tint, only partly open from the bottom side of the lamina

P. populinigrae (Schrank, 1801) (syn.: P. filaginis Boyer de Fonscolombe, 1841)
The species is holocyclic and heteroecious, migrating to the basal parts and leaves of Filago L. and Gnaphalium L. it is cosmopolitic.

\section{References}

Achremowicz, J. 1972: Mszyce (Homoptera, Aphidodea) Niziny Wielkopolsko-Kujawskiej II. - Fragmenta Faunistica 18: 361-392. [In Polish.]

Achremowicz, J. 1975: Pochodzenie, struktura i przemiany fauny mszyc (Homoptera, Aphidodea) Niziny Wielkopolsko-Kujawskiej. — Zeszyty Naukowe AR w Krakowie 33: 1-116. [In Polish.]

Albrecht, A. (ed.) 2013: Atlas of the Aphids of Finland. [www document]. URL http://www.luomus.fi/elaintiede/hyonteiset/tutkimus/kirvat/atlas.htm (Site visited on 22 April, 2013).

Barbagallo, S., Binazzi, A., Bolchi-Serini, G., Martelli, M. \& Patti, I. 1995: Aphidoidea. — In: Minelli, A., Ruffo, S., La Posta, S. (eds.), Checklist delle specie della fauna italiana 43: 13-38, Calderini, Bologna. 57 pp. [In Italian.]

Barczak, T. 1987: Stan badań nad podrodziną Pemphiginae (Homoptera, Aphidoidea, Pemphigidae) w Polsce. - Wiadomości Entomologiczne 7: 27-37. [In Polish.]

Blackman, R. L. \& Eastop, V. F. 2006: Aphids on the world's herbaceous plants and shrubs. - Wiley, Chichester. 1460 pp.

Blackman, R. L. \& Eastop, V. F. 2013: Aphids on the World's Plants. [www document]. URL http://www. aphidsonworldsplants.info/ (Site visited on 22 April, 2013).

Bodenheimer, F. S. \& Swirski, E. 1957: The Aphidoidea of the Middle East. — Weizmann Sciences Press, Jerusalem. 378 pp.

Börner, C. 1952: Europae centralis Aphides: die Blattläuse Mitteleuropas: Namen, Synonyme, Wirtspflanzen, Generationszyklen, - Mitteilungen der Thüringischen Botanischen Gesellschaft. 268 pp.

Bozhko, M. P. 1957: (Contribution to the knowledge of the aphid fauna (Aphidoidea) of the western Ukraine and Moldavia.) - Trudy NII biologii i biologicheskogo fakulteta Kharkov'skovo univiersiteta 30: 223-240. [In Russian.]

Bozhko, M. P. 1971: (Dendrophilous aphids (Homoptera, Aphidinea) of the Dzhanybek field station and its surroundings.) — In: Bozhko, M. P., Lindeman, G. V. \& Pachomova, V. E. (eds.), Zhyvotnye iskusstvennykh lesnykh nasazhdeniy v glinistoy polupustyne: 104 119. Izdatel'stvo “Nauka”, Moskva. 197 pp. [In Russian.]

Bozhko, M. P. 1976: (Aphids of the nutritious plants.) Izdat'elskoe ob'edinenie "Vyshcha Shkola," Kharkov. 135 pp. [In Russian.] 
Çanakçioglu, H. 1966: Türkiye'de orman agaçlarina âriz olan Bitki bitleri (Aphidoidea) üzerine araştirmalar. Istanbul Universitesi Orman Fakultet Dergisi (A) 16: 131-190. [In Turkish.]

Çanakçioglu, H. 1972: Über das Vorkommen von Blattlausarten (Aphidoidea) im türkischen Forst. - Anzeiger für Schädlingskunde und Pflanzenschutz 45: 152 154.

Chumak, V. 2004: Blattläuse der ukrainischen Karpaten. — Mystez'ka Linija, Ushhorod. 160 pp.

Courchet, L. 1879: Étude sur les galles produites par les aphidiens. - Pharmacie Ecole Supérieure de Pharmacie de Montpellier, Montpellier. 106 pp.

Czylok, A. 1983: Zgrupowania mszyc (Homoptera, Aphidodea) wybranych zbiorowisk leśnych okolic Pińczowa. - Acta Biologica Silesiana 13: 114-130.

Czylok, A., Gorczyca, J., Hałaj, R., Klimaszewski, S. M. \& Wojciechowski, W. 1991: Fauna mszyc (Homoptera, Aphidodea) zwałowisk odpadów węglowych i cynkowych województwa katowickiego. - Acta Biologica Silesiana 18: 108-117.[In Polish.]

Czylok, A. \& Wojciechowski, W. 1987: Communites of Aphids (Homoptera, Aphidoidea) of the Xerothermic Vegetation in Niecka Nidziańska. - Acta Biologica Silesiana 6: 36-42.

Danielsson, R. 1976: Gallbildande bladlöss på asp och poppel i Sverige. - Entomologen 5: 1-14. [In Swedish.]

Dunn, J. A. 1960: The formation of galls by some species of Pemphigus (Homoptera, Aphididae). — Marcellia 30: 155-167.

Dzhibladze, A. A. 1968: Aphids (Aphidinea). — In: Proceedings of fauna of surroundings of Tbilisi: 25-50. Metsniereba, Tbilisi.

El-Akkad, S. \& Zalat, S. 2004: Populus galls induced by Pemphigus aphids in Sinai. - Egyptian Journal of Biology 2: 15-19.

Figaj, J. \& Stecki, Z. 1979: Zagadnienie nowej sekcji w rodzaju Populus. — Wiadomości Botaniczne XXIII: 305-309. [In Polish]

Furk, C. \& Prior, R. N. B. 1975: On the life cycle of Pemphigus (Pemphiginus) populi Courchet with a key to British species of Pemphigus Hartig (Homoptera: Aphidoidea). - Journal of Entomology, Series B Taxonomy 44: 265-280.

Gabrid, N. V. 1989: (Aphids of trees and shrubs of the Issyk-Kul region). - ILIM, Frunze. 186 pp. (In Russian.)

González Funes, P. \& Michelena Saval, J.M. 1988: Pulgones (Hom., Aphidoidea) de la provincia de Alicante I. Thelaxidae, Pemphigidae, Drepanosiphidae, Anoecidae y Lachnidae. - Boletín de la Asociación española de Entomología 12: 319-326. [In Spanish.]

Hałaj, R. 1996: Nowe dla Niecki Nidziańskiej gatunki mszyc (Sternorrhyncha: Aphidinea). — Acta Entomologica Silesiana 4(1-2): 24. [In Polish.]

Hałaj, R. 1998: Nowe gatunki mszyc (Homoptera: Aphidinea) dla Wyżyny Śląskiej. — Acta Entomologica Silesiana 5-6: 51.[In Polish.]

Hałaj, R. \& Węgierek, P. 1998: Mszyce (Homoptera:
Aphidinea) rezerwatu przyrody "Segiet" na Wyżynie Śląskiej. — Acta Entomologica Silesiana 5-6: 31-32. [In Polish.]

Heie, O. E. 1980: The Aphidoidea (Hemiptera) of Fennoscandia and Denmark I: Mindaridae, Hormaphidae, Thelaxidae, Anoecidae and Pemphigidae. - Fauna Entomologica Scandinavica 9: 1-236.

Holman, J. 1995: Sternorhyncha: Aphidinea. — In: Rozkošný, R. \& Vanhara, J. (eds.), Terrestrial Invertebrates of the Pálava Biosphere Reserve of UNESCO I. 189-200. Folia Facultatis scientiarium naturalium Universitatis Masarykianae Brunensis. Biologia, Brno. 208 pp.

Holman, J. 2009: Host plant catalog of aphids: Palaearctic region. - Springer. $1140 \mathrm{pp}$.

Holman, J. \& Pintera, A. 1981: Übersicht der Blattläuse (Homoptera, Aphidoidea) der Rumänischen Sozialistischen Republik. - Studie ČSAV 15: 1-125.

Ivanovskaja, O. I., 1977: (Aphids of the western Siberia. I.-II.) - Akademiya Nauk SSSR, Novosibirsk. [In Russian.]

Janežič, F. 1978: Zoocecidiji, nabrani v Istri leta 1978. Zbornik Biotehniske fakultete Univerze Edvarda Kardelja v Ljubljani. Kmetijstvo. Agricultural issue 31: 137-148. [In Slovenian.]

Janežič, F. 1981: Zoocecidiji, nabrani v Istri leta 1980 in 1981. - Zbornik Biotehniske fakultete Univerze Edvarda Kardelja v Ljubljani. Kmetijstvo. Agricultural issue 37: 283-301. [In Slovenian.]

Janežič, F. 1989: Dvajseti prispevek k poznanju živalskih šišk (zoocecidijev) na rastlinach v Sloveniji. - Zbornik Biotehniske fakultete Univerze Edvarda Kardelja v Ljubljani. Kmetijstvo. Agricultural issue 53: 143158. [In Slovenian.]

Juchnevitch, L. A. 1968: (Aphids (Homoptera, Aphidinea) from Eastern Kazakhstan.) — Trudy Instituta Zoologii Akademii Nauk KazSSR 30: 58-95. [In Russian.]

Karwańska, J. 1991: Mszyce (Aphidodea) Wojewódzkiego Parku Kultury i Wypoczynku w Chorzowie. - Acta Biologica Silesiana 6: 108-118. [In Polish.]

Klimaszewski, S. M., Wojciechowski, W., Czylok, A., Gębicki, C., Herczek, A. \& Jasińska, J. 1980: Zgrupowania wybranych grup pluskwiaków równoskrzydłych (Homoptera) i różnoskrzydłych (Heteroptera) w lasach rejonu huty "Katowice". — Acta Biologica Silesiana 8: 22-39. [In Polish.]

Krzywiec, D. 1970: Uzupełnienia do znajomości fauny mszyc (Homoptera, Aphidoidea) Polski ze szczególnym uwzględnieniem Niziny Wielkopolsko-Kujawskiej. — Fragmenta Faunistica 16: 109-121. [In Polish.]

Krzywiec, D. 1982: Materiały do poznania mszyc (Homoptera, Aphidoidea) Polski ze szczególnym uwzględnieniem Niziny Wielkopolsko-Kujawskiej. Fragmenta Faunistica 27: 1-12. [In Polish.]

Lampel, G. 1960: Die morphologischen und ökologischen Grundlagen des Generationswechsels monözischer und heterözischer Pemphiginen der Schwarz- und Pyramidenpappel. - Zeitschrift für Angewandte Entomologie 47: 334-375. 
Lampel, G. 1988: Blattläuse (Sternorrhyncha, Aphidina). - Ergebnisse der wissenschaftlichen Untersuchungen im Schweizerischen Nationalpark 12(13): 500.

Lampel, G. 2001: Beitrag zur Kenntnis der Blattlausfauna Korsikas (Homoptera, Aphidina). — Mitteilungen Schweizerische Entomologische Gesellschaft 74: $105-138$.

Lampel, G. \& Meier, W. 2003: Hemiptera: Sternorrhyncha - Aphidina. Teil 1: Non-Aphididae. - Fauna Helvetica 8: 1-237.

Mamontova, V. A. 1949: (Aphids (Aphidoidea) of the Kaniev biogeographical reserve.) - Trudy Kanevskogo biogeograficheskogo zapovednika KGU 7: 87-116. [In Russian.]

Mamontova, V. A. 1955: (Dendrophilous aphids of Ukraine.) — Izdatel'stvo Akademii Nauk UkrSSR, Kiev. 91 pp. [In Russian.]

Mukhamediev, A. A. 1979: (Aphids of Fergana Valley.). — Izdatel'stvo "FAN" UzbSSR, Tashkent. 78 pp. [In Russian.]

Narzikulov, M. N. 1953: (New data on fauna of aphids of Middle Asia.) - Izvestiya Otdeleniya Estestvennykh Nauk Akademii Nauk TadSSR 55: 55-67. [In Russian.]

Narzikulov, M. N. 1968: (Aphids of the Kondara Gorge and adjacent territories of the Varzob river valley (Tajikistan). — In: Žadin, W. I., Pavlovskij, E. N. \& Narzikulov M. N. (eds.), Ushchel'e Kondara: 5-29. Donish, Dushanbe. 220 pp. [In Russian.]

Nieto Nafría, J. M., Mier Durante, M. P., Binazzi, A. \& Pérez Hidalgo, N. 2002: Hemiptera. Aphididae II. Fauna Ibérica 19: 1-350.

Nieto Nafría, J. M., Andreev, A. V., Binazzi, A., Mier Durante, M. P., Pérez Hidalgo, N., Rakauskas, R. \& Stekolshchikov, A. V. 2012: Fauna Europaea: Aphidoidea. Fauna Europaea, Version 2.5. [www document]. URL http://www.faunaeur.org/ (Site visited on 22 April, 2013).

Olesinski, L. \& Szelegiewicz, H. 1974: Mszyce (Homoptera, Aphidodea) okolic Chrzanowa. - Fragmenta Faunistica 19: 319-347. [In Polish.]

Osiadacz, B. \& Hałaj, R. 2009: The aphids (Hemiptera: Sternorrhyncha: Aphidinea) of Poland. A distributional checklist. - Polish Entomological Monographs 6: $1-96$.

Osiadacz, B. \& Hałaj, R. 2010: Systematic Review of Aphids (Hemiptera: Sternorrhyncha: Aphidomorpha) of Poland with Host Plant Index: A Monographic Survey. - Silesian Natural History Monographs 1: 1192.

Osiadacz, B. \& Hałaj, R. 2011: Masowe pojawy Pemphigus spyrothecae Passerini, 1856 (Hemiptera, Aphidoidea, Eriosomatidae) w Polsce. - Acta Entomologica Silesiana 19: 7-13. [In Polish.]

Osiadacz, B. \& Wieczorek, K. 2003: Mszyce (Hemiptera: Aphidoidea) wybranych parków Bytomia. - Acta Entomologica Silesiana 11: 39-46. [In Polish.]

Pérez Hidalgo, N. \& Nieto Nafría, J. M. 2003: Check-list of Eriosomatinae (Hemiptera, Sternorrhyncha: Aphi- didae) of the Iberian Peninsula and Balearic Islands. — Acta Entomológica Ibérica e Macaronésica 1: 6773.

Pike, N., Whitfield, J. A. \& Foster, W. A. 2007: Ecological correlates of sociality in Pemphigus aphids, with a partial phylogeny of the genus. - BMC Evolutionary Biology 7: 185.

Prinsen, J. D. 1990: Spring migration of the caraway root aphid, Pemphigus passeki Börner (Homoptera: Aphidoidea). - Acta Phytopathologica et Entomologica Hungarica 25(1-4): 143-152.

Remaudière, G. \& Remaudière, M. 1997: Catalogue des Aphididae du monde (Homoptera Aphidoidea). - Institut National de la Recherche Agronomique, Paris. $473 \mathrm{pp}$.

Roberti, D. 1993: Gli Afidi d'Italia (Homoptera-Aphidoidea). - Entomologica 25-26: 3-387. [In Italian.]

Shaposhnikov, G. C. 1964: Suborder Aphidinea-Aphids. — In: Bey-Bienko, G. Y. (ed.), Keys to insects of European part of USSR: 616-799. Israel Program for Scientific Translations Ltd., Jerusalem. 936 pp.

Smith, C. F. 1985: Pemphiginae in North America. — In: Szelegiewicz, H. (ed.), Evolution and biosystematics of aphids: proceedings of the International Aphidological Symposium at Jablonna, 5-11 April, 1981: 277302. Polish Academy of Sciences, Wrocław-Warszawa-Kraków-Gdańsk-Łódź. 510 pp.

Stroyan, H. L. G. 1957: Further Additions to the British Aphid Fauna. - Transactions of the Royal Entomological Society of London 109: 311-360.

Stroyan, H. L. G. 2009: Notes on some British species of Pemphigus Hartig (Homoptera: Aphidoidea) forming galls on Poplar, with the description of a new species. - Proceedings of the Royal Entomological Society of London. Series B, Taxonomy 33: 92-100.

Szelegiewicz, H. 1968: Mszyce - Aphidoidea, Katalog Fauny Polski. - Polish Academy of Sciences, Warszawa. 316 pp. [In Polish.]

Szelegiewicz, H. 1981: Materiały do poznania kserotermofilnych mszyc Wyżyny Małopolskiej (Homoptera, Aphidoidea). - Fragmenta Faunistica 25: 423-433. [In Polish.]

Tashev, D. G. 1985: A catalogue of host plants of the Bulgarian aphids. - Annals of the University of Sofia 76: 85-124.

Urban, J. 2002: Occurrence, development and natural enemies of Pemphigus spyrothecae (Homoptera, Pemphigidae). - Journal of Forest Sciences 48(6): 248-270.

Vereshchagin, B. V., Andreev, A. V. \& Vereshchagina, A. B. 1985: (Aphids of Moldavia.) — Shtiintza, Kishinev. 158 pp. [In Russian.]

Vereshchagin, B. V. \& Vereshchagina, A. B. 1962: Contribution to the fauna of dendrophilous aphids (Aphidoidea) of Moldavia. - Izvestiya Akademii Nauk MoldSSR 3: 17-30.

Whitham, T. G. 1978: Habitat Selection by Pemphigus Aphids in response to response limitation and competition. - Ecology 59: 1164-1176.

Wieczorek, K. \& Osiadacz, B. 2005: Mszyce dendrofilne 
(Hemiptera, Aphidoidea) urządzonej zieleni miejskiej Katowic - część I: Park im. T. Kościuszki. — Acta Entomologica Silesiana 12-13: 155-160. [In Polish.] Wool, D. 2004: Galling aphids: specialization, biological complexity, and variation. - Annual Review of Entomology 49: 175-192.
Zwölfer, H. 1958: Zur Systematik, Biologie und Ökologie unterirdisch lebender Aphiden (Homoptera, Aphidoidea) (Anoeciinae, Tetraneurini, Pemphigini und Fordinae). - Zeitschrift für Angewandte Entomologie 43: $1-52$. 